\title{
USING THE INTERNET TO IMPROVE THE EFFICIENCY OF THE SOCIAL ENTERPRISE BUSINESS MODEL
}

\author{
Małgorzata Kurleto* (1) http://orcid.org/0000-0002-5616-4202
}

\begin{abstract}
Background. Modern technologies, and the Internet in particular, play an essential role in the effective business model of every company. Due to the fact that social enterprises often take over business models from commercial enterprises, a question arises about their applicability in the use of the Internet in social business. The size of the social enterprise and having a strong leader in the organization should be taken into account.

Research. The study identifies the increase of effectiveness of social enterprise business models through appropriate use of the Internet. The analysis attempts to demonstrate the relationship between business models and the social enterprise strategy, emphasizing the important role of the holistic model. The analysis is intended to show the importance of the business model in marketing and management.

Methodology. The study is based on a literature analysis as well as in the empirical part on the results of the author's research. The most important hypothesis of the study assumes that the direct effectiveness of using the Internet is positively associated with the effectiveness and success in creating social value.

Findings. The results of analysis show that the impact of Internet efficiency was high in those social enterprises that used the appropriate business model. The efficiency of using the Internet is positively related to the size of the social enterprise and having a strong leader.
\end{abstract}

Keywords: business model, social enterprise, Internet.

JEL Codes: F69, M29.

* Jagiellonian University. E-mail: m.kurleto@uj.edu.pl. 


\section{INTRODUCTION}

Social enterprises constantly look for new solutions to increase their effectiveness directed towards achieving social goals. Some of the best of these solutions are business models, which become key variables explaining the modern dimension of today's business. The business model being one of the determinants of the company's success enters into relations with the business strategy and processes, together creating a configuration of mutual connections, which shape the ability of the company to achieve high efficiency (Jabłoński, 2015, p. 76). These problems relate to a large extent not only to commercial enterprises but also to social enterprises (SEs). It can be considered (Kurleto, 2016) that a social enterprise is an organized form of aid activity, operating as "market-oriented" in the micro, meso, and macro environment, on the basis of laws applicable in a given country, able to apply business methods for which the implementation of designated missions is more important than profit making. Secondly, a social enterprise is an organized form of aid functioning "market-based" that applies commercial strategies to maximize the potential for achieving financial and social goals. Thirdly, a social enterprise focuses on both economic and social efficiency. In order to generate social value, a SE has to generate commercial value (Ibid.), that is, goods or services that can be sold on the market. Thus, in the activity of a social enterprise, the main social goal depends on the effective achievement of a business goal.

Business models for social enterprises can be described "like the channel that the social entrepreneur converts inputs into outcomes; the generation of both social value (measurable impact) and economic value (revenue)" (Social Enterprise Business Models, 2020, p. 1).

In the last decade social enterprises (defined as the core of social economy), found a tool that has influenced and continues to improve their efficiency. That tool is the Internet.

The end of the twentieth century brought an unprecedented flood of new technologies on this scale. These technologies, and most of the entire Internet, were also distinguished by the fact that their consequences were felt not only by individual industries, selected enterprises, but they concerned most business entities, as well as social enterprises. Nowadays, the concept of the business model is 
often discussed, including its relationship with modern technology (Baden-Fuller, Haefliger, 2013; Saebi, Foss, \& Linder, 2019).

This analysis hopes to further the discussion aimed at resolving the essence of the social enterprise business model and the relationship between the SE and the Internet. The purpose of this analysis is to identify the elementary issues related to business models of the social enterprise. The most important hypothesis in this analysis assumes that the direct effectiveness of using the Internet is positively associated with the effectiveness of the business model of SE. Two further hypotheses were also adopted, the second states that the effectiveness of the business model depends on having a "strong leader" of the social enterprise, and the third that the effectiveness of the business model depends on the large size of social enterprise.

The conducted analysis is based on a literature review and the author's questionnaire research. The main inspiration for this study were the results of the National Development Committee social economy survey. According to the results of this survey, the use of new technologies (including the Internet) by social enterprises in order to increase the effectiveness of creating socio-economic value was used especially in building marketing strategies and brand promotion ( $52 \%$ of the surveyed social enterprises) and strengthening the market position of the current offer (47\% of the surveyed social enterprises) (Ekonomia spoteczna..., 2019, p. 16). The aforementioned survey concerned only marketing problems but it seems that the Internet is important also for the creation of social enterprises and their business model, as well as for the organization and management of social enterprises. The author's own research concerning the Polish model of social enterprise was conducted in the period 2015-2016. This research is based on a questionnaire study of the social enterprise model, which covered 718 entities of a dual economic and social nature (Kurleto, 2016). The study took into account eight business models of social enterprises, which use modern technologies (including the Internet). The study provided the opportunity to identify both the most common and the most effective business models. The presented themes allow for showing the Internet's impact on the effectiveness of the SE business model in close relation to different possibilities of using the Internet, taking into account the variety of goals and functions, including marketing management and creation of the social enterprise. 


\section{BUSINESS STRATEGY AND BUSINESS MODEL IN THE HOLISTIC SCHEME OF SE}

The concepts of the business model and business strategy are key points in management sciences, though both these terms are the object of an ongoing methodological debate. Drzewiecki (2011) stated that the business model, depending on the approach, may contain a very diverse set of elements including both the organization's interior as well as its surroundings, partners, elements of the value chain, and even of the competitive strategy. In the management sciences, the concept of strategy is understood in many ways, often in a much broader way than presented in this study. According to Wierzbiński (2015), the business strategy is a set of long-term goals of the company's operations, while the business model is a description of the enterprise architecture whose implementation simplifies possibility of achieving these goals. In a simplified way, it can be stated that the business model represents what the company is, while the strategy describes what the company wants to achieve and how it intends to do it. The review of the definition shows that the business model is more focused on the company's interior and on the creation of economic value (Ugolini \& Smith, 2015; Ge, Xu, \& Pellegrini, 2019).

The company's business model is usually easy to understand. Transparency and easy "readability" of the business model is particularly important in relation to social enterprises. Many experts on business models of social enterprises have emphasized that the mentioned models are the axis of strategic thinking, building the future of these enterprises for which getting a profit is important in the context of the possibilities of achieving the social goal (Duczkowska-Piasecka, Poniatowska-Jaksch, \& Duczkowska-Małysz, 2015; Sutter, Bruton, \& Chen, 2019).

It seems to be the most appropriate to assume that the business model and strategy are two distinct elements that combine strong relationships of purposefulness and compatibility (the examination of precedence-successiveness allowed to assume that on the timeline of the economic enterprise the business model is ahead of the adopted strategy) (Nogalski \& Falencikowski, 2015). The business model should allow for the achievement of the assumed goals (economic and social in SE). The "organizational dimension" of the innovative business 
model allows this model to become the "architecture" of a business that connects the organizational structure of the enterprise and leads to the creation or interception, delivery, and monitoring of value. The model should have capabilities that require both transformational leadership and a flexible organization. The business model carries the general logic of the offered value proposition. The dynamic functions of the business model should be used as part of a proper management strategy, to be effective. To achieve a competitive advantage a consistent, coherent and favorable strategy is needed. It seems that nowadays a part of this strategy is based on using the Internet and creating one's own business model.

There is no doubt that from the point of view of the SE, the approach focuses on the effectiveness of the business model, both economic and social (Boudreaux, Nikolaev, \& Klein, 2019). It should be noted that the innovation, sustainability, and entrepreneurial approach is of particular importance for the SE (Bansal, Garg, \& Sharma, 2019). Another important aspect is the management strategy of the SE, which can broadly characterized as the business manager's behavior, expressed by his or hers attitude (Heinecke, Kloibhofer, \& Krzeminska, 2014; Ge et al., 2019).

In all models used in the research conducted by other authors, the most important feature is undoubtedly the operation of social enterprises - autonomous entities-not-for-profit, but for achieving social benefits. It is important to build a holistic model of a social enterprise, in which the entrepreneur motivated by the vision, and at the same time stimulated by available sources and opportunities (including legal and institutional), takes measures that allow the implementation of set goals. The main motivation, available resources, and visually stimulating capabilities of the SE are focused on building a holistic model. In the holistic and integrated model, the cause of the action (e.g. social assistance) is the beginning of the activity indicating at the same time its end, that is the welfare of the recipient. The motivated purpose of the action (purposeful cause) is an idea which considers the opportunity (the causative cause). The beneficial influence of the environment can lead to the creation of a social enterprise aiming at fulfilling its mission (in which the final goal is included). The implementation of the idea, requires resources and opportunities (material cause) and allows for deliberate action. A social enterprise must also have organizational and legal bases that define the type of social 
action. In the process of creating a SE, a formal cause interactively influences formal reasons, for example by stimulating the issuance of regulations beneficial for the development of social enterprises (Muralidharan \& Pathak, 2018). It is important to emphasize the flexibility of the holistic model, which allows for the creation of various integrated influences and connections and those operating on the basis of feedback. Even formal reasons (e.g. new provisions beneficial for social enterprises) affect material reasons, such as the development of resources, and increase of opportunities that give a chance of purposeful social action (Goldstein, Hazy, \& Silberstang, 2010; Su, Zhou, \& Zhang et al., 2019).

Many authors emphasize that in practice one business model is very often not enough for social enterprises (Gebauer, Saul, Halidmann, $\&$ Kramer, 2017). Understanding and utilizing the need to use business models for SE in relation to using of the Internet can increase effectiveness of its operation. Fernández-Laviada, López-Gutiérrez, and Pérez (2020) emphasize the role of the Internet in management, especially at the stage of creation of a social enterprise. The Internet, including in particular social networking sites, generates and distributes content internally and outside of specialized practices of SE. Social enterprises are starting to adopt mechanisms to connect with their customers, what simplifies both marketing and management. This kind of impact of modern technology on marketing and management is highly relevant to the analyzed enterprises. The understanding of these influences includes Internet "software" (applications) of the particular business model of SE in its interaction with the internal and external environment.

\section{USE OF THE INTERNET IN RELATION TO SOCIAL ENTERPRISES}

The dynamics of environmental changes including modern information technology (inter-process communication, IPC) development means that modern social enterprises must quickly and efficiently use all opportunities to successfully conduct their business. An aptly selected SE business model is associated with the availability and appropriate adaptation of the Internet information resource. The Internet is increasingly seen as a rich source of valuable information and as one of 
the most efficient tools that enables quick acquisition of information. Under the influence of the spread of the Internet, social enterprises are constantly evolving; their "business" face is radically changing. The Internet is extremely open. Its dynamic nature also significantly translates into models and strategies implemented by enterprises in the network. The Internet allows gaining competitive advantage in many fields, including: 1) marketing, 2) creating and growing of social business, and 3) management. Subsequent paragraphs provide a closer analysis of these three areas.

Marketing. There is no doubt that the Internet is the most useful in the field of SE marketing. For many SEs, the ability to use the opportunities offered by the Internet becomes necessary to survive on the market. By using the Internet, it has become possible for social enterprises to create their products and services more efficiently, promote them, conduct marketing research and market analyses. The Internet as a source of information is increasingly used in the decision-making process and makes it possible to reach more customers with offers. The most important aspects of this development are interactivity and individualization in customer relations, access to information, choices, convenience, saving time and costs, creating new communities, entertainment, and trust (Wyrobek, 2011). Interactive communication is a separate chapter in marketing connections, helping to solve many existing problems. Interactive communication used, for example, on the Internet, enables conversation on a global scale, even for small enterprises. The Internet network is above all a mine of cheap and up-to-date information about the market, legal provisions, financial regulations, events of significant importance, or market opportunities. Of course, access to the network also allows quick and cheap contact with clients and contractors. The network provides the opportunity to inform about the mission of a social enterprise and to advertise its offer. Among online tools useful for entrepreneurs, online sales systems occupy an important place. It is possible to use them in various dimensions: from participation in online auctions to launching one's own online store. Selling with the help of the Internet may be the only form of commercial activity or it may complement sales carried out by traditional methods. There are many examples of various types of ads, banners, multimedia ads, social media ads, email marketing, and online advertising. The main advantage of Internet marketing over traditional advertising is the ability to immediately publish 
information and content that is not limited in terms of geography and time (Wyrobek, 2011). To this end, emerging areas of interactive advertising pose new challenges to advertisers who have previously used other strategies.

Creating and growing of social business. Many social enterprises have started to see the Internet not only in advertising and marketing, but in the creating and developing of "social business," as well. The information supporting SE activities is useful in setting up a business and developing a business plan, in the recommendation, they are to constitute a forum for discussion, exchange of opinions and support for future and current social entrepreneurs. These types of portals are a "living interactive guide" of the social entrepreneur. The most important thing for them starting their business is obtaining the right financial resources allowing them to operate with the selected business model. The added value generated by the network consists mainly in directing activities, providing useful information and facilitating contact. The Internet is also a kind of mega social business center. Many failures of Internet strategies have their origin in the perception of the network solely from the perspective of its advantages and capabilities. Every online venture, especially a social enterprise, requires a rational approach both from the planning and implementation point of view. It is also worth remembering that the Internet is a constantly growing business channel, which forces social enterprises actively operating online to constantly update knowledge in this area. A properly constructed social enterprise website increases the chances of being seen by a search engine (Wyrobek, 2011).

Management. The Internet is widely used in the area of the relationship between the business model of SE and strategic management (Mack, Marie-Pierre, \& Redican, 2016). The study conducted by Sanchis-Palacio, Campos-Climent, and Mohedano-Suanes (2013) shows the existence of a statistically significant relationship between the use of strategic management tools and the effectiveness of WISEs SE management. Such management includes thoughtful strategies and biasness models, important in the decision-making process. Frączkiewicz-Wronka and Wronka-Pośpiech (2014) stated that information and communication technologies (ICT) can help in managing social enterprises and in creating cooperation networks. There are many examples of these collaborative and successful social networks: Ashoka (the largest network of social entrepreneurs in the world, with 
nearly 3,000 fellows in 70 countries), Carnegie, Aga Khan, and many others (Kurleto, 2013). A very important part of using the Internet in $\mathrm{SE}$ management is Electronic Document Management, which concerns the management of various types of documents in the enterprise with the use of computer programs and mass memory (Barnes, 2018). E-management is also the use of management styles and methods other than traditional methods, because e-management is a solution in which we apply the principles of decentralization to a greater extent, and the basic method in decision support is management by goals (Ibid.). E-management includes, among others: e-business (electronic business), that is, conducting business referred to as business using computer networks (Ibid.). Monitoring of what is happening in the network, browsing websites, catalogues, and databases allows maintaining good orientation in the environment, which is an important element of social enterprise management.

\section{EFFECTIVENESS OF BUSINESS MODELS IN CORRELATION WITH INTERNET USE}

The author's research conducted in Poland on the combination of the SE business model with the use of the Internet examined the assumed hypothesis related to the problem of efficiency of social enterprises. Based on the data obtained from 718 entities invited to participate in the study, the frequency of individual responses was counted and compared.

Table 1. Business models of the social enterprise (SE) in research conducted in Poland

\begin{tabular}{|l|c|}
\hline $\begin{array}{l}\text { 1. Complex (subject-related) mixed (subject-related), and combined (subject-specific } \\
\text { and subject-related) model }\end{array}$ & 16 \\
\hline $\begin{array}{l}\text { 2. The fundraising and entrepreneurial model (this is a social enterprise founded } \\
\text { on the canvas of a social organization that has taken up economic activity) }\end{array}$ & 26 \\
\hline $\begin{array}{l}\text { 3. Model of supporting and market relations with the participation of integrated } \\
\text { and mission-oriented social enterprises }\end{array}$ & 22 \\
\hline $\begin{array}{l}\text { 4. Market player model. In this model, a social enterprise bases its activity mainly } \\
\text { on the authority and abilities of the individual entrepreneur }\end{array}$ & 6 \\
\hline $\begin{array}{l}\text { 5. Model of philanthropic operator performing in the network. In this model, } \\
\text { the social enterprise belongs to the charity network of domestic or foreign } \\
\text { philanthropic enterprises }\end{array}$ & 6 \\
\hline
\end{tabular}




\begin{tabular}{|l|r|}
\hline 6. Model of business intermediation & 5 \\
\hline 7. The patented model including Franchising Model & 5 \\
\hline $\begin{array}{l}\text { 8. Employment model operating in the form of a social cooperative } \\
\text { (social enterprises established for people at risk of social exclusion) }\end{array}$ & 14 \\
\hline
\end{tabular}

Source: data extracted from the table included in the own study; Kurleto, 2016, p. 226.

Table 2. The percentage effectiveness measured by the amount of income from PLN 10,000 to 100,000, and above 100,000

\begin{tabular}{|l|c|c|c|}
\hline $\begin{array}{c}\text { Eight business models of } \\
\text { social enterprises identified } \\
\text { in research conducted in } \\
\text { Poland }\end{array}$ & $\begin{array}{c}\text { A. Percentage } \\
\text { of effectiveness } \\
\text { obtained according } \\
\text { to the respondents } \\
\text { thanks to use of } \\
\text { modern technology, } \\
\text { including the } \\
\text { Internet }\end{array}$ & $\begin{array}{c}\text { B. Percentage } \\
\text { of effectiveness } \\
\text { obtained } \\
\text { according to the } \\
\text { respondents by } \\
\text { having a strong } \\
\text { organization } \\
\text { leader }\end{array}$ & $\begin{array}{c}\text { C. Percentage } \\
\text { of effectiveness } \\
\text { obtained } \\
\text { according to the } \\
\text { respondents by } \\
\text { having a large } \\
\text { organization }\end{array}$ \\
\hline $\begin{array}{l}\text { 1. Complex (subject-related) } \\
\text { mixed model }\end{array}$ & 63 & 61 & 62 \\
\hline $\begin{array}{l}\text { 2. The fundraising } \\
\text { \& entrepreneurial model }\end{array}$ & 72 & 71 & 70 \\
\hline 3. Model of supporting & 64 & 64 & 63 \\
\hline 4. Market player model & 70 & 68 & 70 \\
\hline $\begin{array}{l}\text { 5. Model of an operator in } \\
\text { philanthropic network }\end{array}$ & 71 & 69 & 69 \\
\hline $\begin{array}{l}\text { 6. Model of business } \\
\text { intermediation }\end{array}$ & 70 & 65 & 64 \\
\hline 7. The patented model & 66 & 61 & 62 \\
\hline 8. Employment model & 63 & 68 & 69 \\
\hline
\end{tabular}

* The research was conducted on large organizations with annual revenue of at least PLN 10,000 to 100,000 , and above 100,000 (Kurleto, 2016).

Source: author's own research.

The analysis showed that for SE entities any business model can be effective if it properly uses modern technologies (including the Internet). The four business models of SE: 1) fundraising and entrepreneurship, 2) market player from the philanthropic network, 3) operator model operating in the network, and 4) the business intermediation model obtained the highest percentage of opinions highly evaluating their effectiveness, which is mainly due to the use of the Internet, a strong leader, and the size of a social enterprise (measured by the amount of annual revenue). Due to the very small percentage differences in the evaluation of the causes of effectiveness (A, B, C; see Table 2) of 
business models, it did not seem reasonable to conduct their Tests of Statistical Significance. Undoubtedly, in practice, these three reasons can jointly determine the high efficiency of the SE business model.

During the research on the business model, the impact of the choice of the SE business model on the organization's revenue structure was also determined. As before, three groups were distinguished in the structure of annual income. The statistical analysis determined that $X^{2}=96.33$, which is a value greater than the critical one for the significance level of $\alpha=0.05$ and 16 degrees of freedom $X_{\mathrm{kr}}^{2}=26.30$. Therefore, it can be assumed that the business model affects the revenue structure.

Table 3. The relationship between the business model and the annual revenue structure in PLN. The median was calculated keeping five intervals

\begin{tabular}{|c|c|c|c|c|}
\hline No. & Up to 10,000 (\%) & $\begin{array}{c}\text { From 10,000 to } \\
\mathbf{1 0 0 , 0 0 0} \mathbf{( \% )}\end{array}$ & $\begin{array}{c}\text { Above } \mathbf{1 0 0 , 0 0 0} \\
\mathbf{( \% )}\end{array}$ & Median in PLN \\
\hline $\mathbf{1 .}$ & 38 & 32 & 30 & 43.1 \\
\hline $\mathbf{2 .}$ & 20 & 43 & 37 & 73.6 \\
\hline $\mathbf{3 .}$ & 54 & 31 & 15 & 9.1 \\
\hline $\mathbf{4 .}$ & 10 & 41 & 48 & 96.3 \\
\hline $\mathbf{5 .}$ & 29 & 43 & 29 & 55.0 \\
\hline $\mathbf{6 .}$ & 11 & 83 & 6 & 52.0 \\
\hline $\mathbf{7 .}$ & 33 & 48 & 19 & 41.2 \\
\hline $\mathbf{8 .}$ & 16 & 49 & 36 & 73.4 \\
\hline
\end{tabular}

Source: data extracted from the table included in the own study; Kurleto, 2016, p. 227.

The mere fact of having the highest value Internet resources is not a determinant of the highest efficiency of a social enterprise. On the other hand, the impact of Internet efficiency was high in those social enterprises that used the appropriate business model, in particular in the fundraising and entrepreneurial model. The scale of benefits from using the Internet depends on the level of sophistication of the technology used. The efficiency of using the Internet is positively related to the size of the SE and to having a strong organization leader. The results of the study provide empirical confirmation for the role of the Internet as a leverage of SE resources. The presented research results confirm all three assumed hypotheses. 


\section{CONCLUSIONS}

The results of study show that one of the most important factors influencing the effectiveness of social enterprise is to use the right business model, which properly utilizes modern technologies (including the Internet).

Literature research has shown that modern technology, especially the Internet, can support social entrepreneurship initiatives by democratizing access to information and creating business value (Rey-Martí, Mohedano-Suanes, \& Simón-Moy, 2019). Social enterprises owe to the Internet gains in the spheres of: increasing self-sufficiency, employability, solving social problems, assistance in choosing the right and successful business model for an SE; creating social networks in many initiatives, and making it possible to transfer the results of one's own experience to other social entrepreneurs (Rattner, 2014). The concept of the business model of SE appeared in the theory and practice of management along with the innovations resulting from the need to redefine the existing principles of social functioning of the enterprise. The business model of SE in strategic management is a way to secure profits that can be used for social purposes, based on long-term internet activity. The business model can be the basis for determining the management strategy.

The research conducted by the author has shown a positive relationship between effectiveness of SE business models and the use of modern technologies (including the Internet). The research indicated that the use of the Internet by a social enterprise has a large impact on the efficiency of operations by directly affecting the business process in order to gain a competitive advantage. Furthermore, the survey showed that the effectiveness of the business model depends on having a "strong leader" of SE and also takes into account the large SE size.

The problem of maximizing the effectiveness of SE activities is related to the efficiency of the social entrepreneur, who tries to harness the influence of the Internet to achieve the desired social mission and business results. It should be stated that the individual organization's characteristics determine the indirect effectiveness of Internet use. The analysis expressed that social enterprises owe their exceptional effectiveness to their members, in particular leaders and large size of the $\mathrm{SE}$. The above statement is confirmed by the research. The conducted 
survey showed that any SE business models can be effective, if they properly use modern technologies (including the Internet). The most effective business models for SEs turned out to be the entrepreneurial model, model of market player, model of philanthropic operator performing in the network, and intermediation model business. The study also found that the choice of the SE business model undoubtedly influences the structure of the annual income of a social enterprise.

\section{REFERENCES}

Baden-Fuller, C., Haefliger, S. (2013). Business Models and Technological Innovation. https://www.sciencedirect.com/science/article/pii/S0024630113000691 (Accessed: $11^{\text {th }}$ March 2020).

Bansal, S., Garg, I. \& Sharma G.D. (2019). Social entrepreneurship as a path for social change and driver of sustainable development: A systematic review and research agenda. Sustainability, 11(4), 1091.

Barnes, D. (2018). Operations Management. London: Red Globe Press.

Boudreaux, C.J., Nikolaev, B.N. \& Klein, P. (2019). Socio-cognitive traits and entrepreneurship: The moderating role of economic institutions. Journal of Business Venturing, 34, 178-196.

Drzewiecki, J. (2011). Model biznesu a strategia organizacji: Podobieństwa, różnice. Nauki o Zarzadzaniu. Management Science, 8.

Duczkowska-Piasecka, M., Poniatowska-Jaksch, M. \& Duczkowska-Małysz, K. (2015). Nowe wyzwania stojace przed przedsiębiorstwem - implikacje dla zarządzania. In: M. Poniatowska-Jaksch (Ed.), Nowe myślenie w zarzadzaniu strategicznym przedsiębiorstwem (pp. 15-47). Warszawa: OW SGH.

Ekonomia społeczna $w$ Polsce $w$ nowej perspektywie finansowej 2020+. wnioski $i$ rekomendowane rozwiazania (2019). https://www.ekonomiaspoleczna.gov. pl/download/files/EKONOMIA_SPOLECZNA/ES_2021-2027.pdf(Accessed: $18^{\text {th }}$ February 2020).

Fernández-Laviada, A., López-Gutiérrez, C. \& Pérez, A. (2020). How does the development of the social enterprise sector affect entrepreneurial behaviour? An empirical analysis. Sustainability, 12.

Frączkiewicz-Wronka, A. \& Wronka-Pośpiech, M. (2014). The use of ICT USE for achieving the objectives of business model: Social enterprise perspective. Journal of Management Studies, 10(2), 33-42. 
Ge, J., Xu, H. \& Pellegrini, M.M. (2019). The effect of value co-creation on social enterprise growth: Moderating mechanism of environment dynamics. Sustainability, 11(1), 250.

Gebauer, H., Saul, C., Halidmann, M. \& Kramer S. (2017). When one business model is not enough for a social business. Strategic Direction, 33(1), 10-12.

Goldstein, J.K., Hazy, J. \& Silberstang J. (2010). A complexity science model of social innovation in social enterprise. Journal of Social Entrepreneurship, 1(1), 101-125.

Heinecke, A., Kloibhofer, M. \& Krzeminska, A. (2014). Leadership in Social Enterprise. http://www3.weforum.org/docs/WEF_leadership_in_social_enterprise_2014. pdf (Accessed: 14 ${ }^{\text {th }}$ June 2020).

Jabłoński, A. (2015). Conference paper. https://zarzadzanie.uni.lodz.pl/LinkClick. aspx?fileticket=NquC2XOXna4\%3D\&tabid=1610 (Accessed: $20^{\text {th }}$ February 2020).

Kurleto, M. (2013). The role of venture philanthropy as the distinctive domain of social entrepreneurship (contemporary trends). Electronic International Interdisciplinary Conference, September 2-6.

Kurleto, M. (2016). Model przedsiębiorstwa społecznego. Warszawa: Difin.

Mack, E.A., Marie-Pierre L. \& Redican K. (2016). Use of internet and social media applications. Telecommunications Policy, 41(2), 636. https://www.researchgate. net/publication/311751_Entrepreneurs\%27_use_of_internet_and_social_media_applications (Accessed: $14^{\text {th }}$ April 2020).

Muralidharan, E. \& Pathak, S. (2018). Sustainability, transformational leadership, and social entrepreneurship. Sustainability, 10, 567.

Nogalski, B. \& Falencikowski, T. (2015). Modele biznesów jako nowy obszar badań w naukach o zarządzaniu. In: J. Rokita (Ed.), Nowe obszary badań w naukach o zarzqdzaniu (pp. 80-94). Katowice: Górnośląska Wyższa Szkoła Handlowa im. Wojciecha Korfantego.

Rattner, J. (2014). Five Ways Social Entrepreneurs Use Technology to Increase Their Impact. https://www.forbes.com/sites/ashoka/2014/12/10/five-ways-social-entrepreneurs-use-technology-to-increase-their-impact/\#4ef2b93e14cc (Accessed: $9^{\text {th }}$ June 2020).

Rey-Martí, A., Mohedano-Suanes, A. \& Simón-Moy, W. (2019). Crowdfunding and social entrepreneurship: Spotlight on intermediaries. Sustainability, 11(4), 1175.

Saebi, T., Foss, N.J. \& Linder, S. (2019). Social entrepreneurship research: Past achievements and future promises. Journal of Management, 45, 70-95. 
Sanchis-Palacio, J.R., Campos-Climent, V. \& Mohedano-Suanes, A. (2013). Management in social enterprises: The influence of the use of strategic tools in business performance. International Entrepreneurship and Management Journal, 9(4), 541-555.

Social Enterprise Business Models (2020). https://learn.marsdd.com/article/social-enterprise-business-models (Accessed: $27^{\text {th }}$ November 2020).

Su, X., Zhou, Y., Zhang, S. (2019). Social entrepreneurship from the perspective of opportunity: Integration analysis based on Timmons process model. JHRSS, $7(3), 438-461$.

Sutter, C., Bruton, G.D. \& Chen, J. (2019). Entrepreneurship as a solution to extreme poverty: A review and future research directions. Journal of Business Venturing, 34, 197-214.

Ugolini, M. \& Smith, E.A. (2015). A Hybrid Approach to Enterprise Business Models, 1-6. http://www.aeit.it/man/CA2015/atti/sessione_B1/B1_17.pdf (Accessed: $27^{\text {th }}$ March 2020).

Wierzbiński, M. (2015). Model biznesowy a strategia i zarządzanie strategiczne. Prace Naukowe Uniwersytetu Ekonomicznego we Wrocławiu, 398, 481-499. Wyrobek, H. (2011). E-zarządzanie w działalności organizacji. Zeszyty Naukowe Uniwersytetu Przyrodniczo Humanistycznego w Siedlcach, 91, 91-104.

\title{
WYKORZYSTYWANIE INTERNETU W CELU ZWIĘKSZENIA EFEKTYWNOŚCI MODELU BIZNESU PRZEDSIĘBIORSTWA SPOKECZNEGO
}

\begin{abstract}
Abstrakt
Kontekst. Nowoczesne technologie, w tym zwłaszcza Internet, odgrywają istotną rolę w efektywnym modelu biznesowym każdej firmy. W związku z tym, że przedsiębiorstwa społeczne często przejmują modele biznesowe z przedsiębiorstw komercyjnych, pojawia się pytanie o możliwości ich stosowania w zakresie wykorzystania Internetu w biznesie społecznym. Należy przy tym brać pod uwagę rozmiary przedsiębiorstwa społecznego i posiadanie silnego lidera w danej organizacji.

Badanie. Badanie ma na celu zidentyfikowanie wzrostu efektywności modeli biznesowych przedsiębiorstw społecznych poprzez odpowiednie wykorzystanie Internetu. Analiza jest próbą wykazania związku między modelami biznesowymi a strategia przedsiębiorstwa społecznego, podkreślając ważną rolę modelu holistycznego. Analiza ma zamiar wykazać znaczenie modelu biznesu w marketingu i zarządzaniu.
\end{abstract}


Metodologia. Badanie opiera się na analizie literatury, a także w części empirycznej na wynikach badań autora. Najważniejsza hipoteza badania zakłada, że bezpośrednia skuteczność korzystania z Internetu jest pozytywnie związana ze skutecznościa i sukcesem w tworzeniu wartości społecznej przedsiębiorstwa.

Rezultaty. Wyniki analizy pokazuja, że wpływ efektywności Internetu był duży w tych przedsiębiorstwach społecznych, które stosowały odpowiedni model biznesowy. Efektywność korzystania z Internatu jest pozytywnie związana z wielkością przedsiębiorstwa społecznego i posiadaniem silnego lidera.

Słowa kluczowe: model biznesowy, przedsiębiorstwo społeczne, Internet. 